\title{
The Relationships between Destination Brand Image, Destination Brand Loyalty and Word of Mouth Behaviour
}

\author{
Ph.D. Candidate Çiğdem Unurlu (Trakya University, Turkey) \\ Prof. Dr. Ayşe Akyol (Trakya University, Turkey) \\ Assoc. Prof. Dr. Dilek Altaş (Marmara University, Turkey)
}

\begin{abstract}
This article documents a study and model of the destination brand image, destination brand loyalty and wordof-mouth behaviour (WOM). Therefore, the literature review consists of three parts namely destination brand image, destination brand loyalty and word-of-mouth behaviour. Destination brand image can be defined as the reasoned perceptions consumers attach to specific brands. Destination brand loyalty can be defined as the main source of customer-based brand equity. Brand loyalty was defined as the attachment a customer has to a brand. Lassar et. al. noted that brand equity stems from the grater confidence that consumers place in a brand than they do in its competitors. This confidence translates into consumers' loyalty and their willingness to pay a premium price for the brand. Word of mouth behaviour can be defined as informal communications directed at other consumers about the ownership or characteristic of particular goods and services and/or their sellers. In order to explore the relationship between destination brand image, destination brand loyalty and word-of-mouth behaviour, a two phase research design (exploratory and descriptive) was adopted and conducted. This study was based on the measures of Boo et all (2009), and Kim et all (2011) because their instruments had been developed, tested, refined and yielded reliable results. The questionnaire items were scored on a 5 point Likert scale, ranging from "strongly disagree" to "strongly agree". A cross sectional design was used for the data collection. Data is analysed by using SPSS.
\end{abstract}

\section{Introduction}

The evaluation of destination image has been the subject of much attention in social science literature. Previous studies showed that destination image will influence tourists in the process of choosing a destination, the subsequent evaluation of the trip and in their future intentions. Furthermore, past research across fields has emphasized the importance of understanding the forces, which influence image development. Goodall noted that knowing the factors influencing image would help identify target markets (Jalilvand et. al., 2012:137). Gitelson and Crompton notes that numerous attractions and destination areas, such as beaches or resorts, are heavily reliant on repeat visitation. Petrick finds that loyal visitors were more likely to return in the future, spread positive word of mouth, and hence offer a lower risk and more profitable target market. Thus, many destinations have adopted a business strategy focused on encouraging tourists to become repeat visitors (Liu et. al., 2012: 119).

\section{Destination Brand Image}

The concept of "image" that has been studied for several decades in such disciplines as social and environmental psychology, marketing, and consumer behavior, was introduced into tourism studies in the early 1970s by Hunt, Mayo, and Gunn and has since become one of the most researched topics in the field (Stepchenkova and Morrison, 2008: 549).

Brand image has been considered as the reasoned or emotional perceptions consumers attach to specific brands (Boo et. al., 2009: 221). Destination image is defined as an individual's overall perception or the total set of impressions of a place. It is regarded as the mental portrayal of a destination. A destination's image can be developed based on the estimation or understanding of a region's characteristics (Jalilvand et. al., 2012: 138).

Destination image in tourism research is an overall representation of beliefs, ideas, and impressions of a travel destination (Lee and Locshin, 2011: 11). Destination image can be defined as the expression of all knowledge, impressions, prejudices and emotional thoughts an individual or group has of a particular object or place (Sun et. al., 2013: 13).

Destination image is associated with a subjective interpretation of tourists' feelings and beliefs toward a specific destination. Destination image is a key determinant influencing tourists' attitudes toward the destination (Veasna et. al., 2013: 513).

Destination brand image was measured using by Boo et. al. (2009: 233)'s four items destination brand image scale anchored with strongly disagree (1) and strongly agree (5). 


\section{Destination Brand Loyalty}

Even though the examination of loyalty started in 1923 with Copeland's study of "brand insistence" it is still one of the most frequently examined topics. The concept of brand loyalty has been recognized as a major driving force and one of the most important indicators of success in the marketing and tourism literature (Sun et. al., 2013: 3). Consumer loyalty is defined as the commitment to re-buy a product or service in the future. Scholars have incorporated loyalty into their analyses of tourism/leisure products, destinations (Lee and Shen, 2013: 77).

The concept of brand loyalty has been recognized as a major driving force and one of the most important indicators of success in the marketing and tourism literature. As suggested by Assael, "success depends not on the first purchase but on repurchase. It is unlikely that any brand can survive over time without some degree of loyalty" (Sun et. al., 2013: 3). Brand loyalty is defined as "a deeply held predisposition to re-patronize a preferred brand or service consistently in the future, causing repetitive same brand purchasing, despite situational influences and marketing efforts having the potential to cause switching behavior". Aaker views loyalty as "the attachment that a customer has to a brand" (Pike and Bianchi, 2011: 3).

Repeat purchases or recommendations to other people are most usually referred to as consumer loyalty in the marketing literature. The concept and degree of loyalty is one of the critical indicators used to measure the success of marketing strategy (Yoon and Uysal, 2005: 48).

This study limited brand loyalty to the attitudinal and behavioral elements and proposes a significant relationship between brand value and brand loyalty. Destination brand loyalty was measured using by Boo et. al. (2011)'s four items destination brand loyalty scale anchored with strongly disagree (1) and strongly agree (5).

\section{Word-of-Mouth Behaviour}

Word of mouth (WOM) is informal advice passed between consumers. It is usually interactive, swift, and lacking in commercial bias. WOM is a powerful influence on consumer behavior (East et. al., 2008: 216). Wordof-mouth communications have received extensive attention from both academics and practitioners for decades. Since the early 1950s, researchers have demonstrated that personal conversations and informal exchange of information among acquaintances not only influence consumers' choices and purchase decisions, but also shape consumer expectations, pre-usage attitudes, and even post-usage perceptions of a product or service. Some research has reported WOM influence as greater than print ads, personal selling, and radio advertising (Bruyn and Lilien, 2008: 152).

In marketing, word of mouth (WOM) is normally used to describe advice from other consumers. The interactivity, speed, and lack of commercial bias of WOM make it a very effective source of information about prospective consumer choices, particularly with regard to services for which pre-purchase experience may be limited (East et. al., 2007: 176).

Word-of-mouth behaviour was measured using by Kim et. al. (2011)'s three items positive word-of-mouth scale anchored with strongly disagree (1) and strongly agree (5).

\section{Methodology}

This article documents a study of the destination brand image and destination brand loyalty associated with word of mouth behaviour. In particular, the research objective is to examine empirically and investigate variations in word-of-mouth behaviour which may be related to destination brand image and destination brand loyalty.

In order to explore the relationship between destination brand image, destination brand loyalty and word-ofmouth behaviour, a two phase research design (exploratory and descriptive) was adopted and conducted. To be able to explore the link between destination brand image, destination brand loyalty and word-of-mouth behaviour three measurement instruments were utilised. The questionnaire items were scored on a 5 point Likert scale, ranging from "strongly disagree" to "strongly agree". A cross sectional design was used for the data collection. Data was analysed by using SPSS.

\section{Research Model}

The research objective is to examine empirically and investigate variations in word-of-mouth behaviour which may be related to destination brand image and destination brand loyalty. Therefore, this study was based on the measures of Boo et. al. (2009), and Kim et. al. (2011) because their instruments had been developed, tested, refined and yielded reliable results.

These independant and dependant variables can be seen in the below figure. 


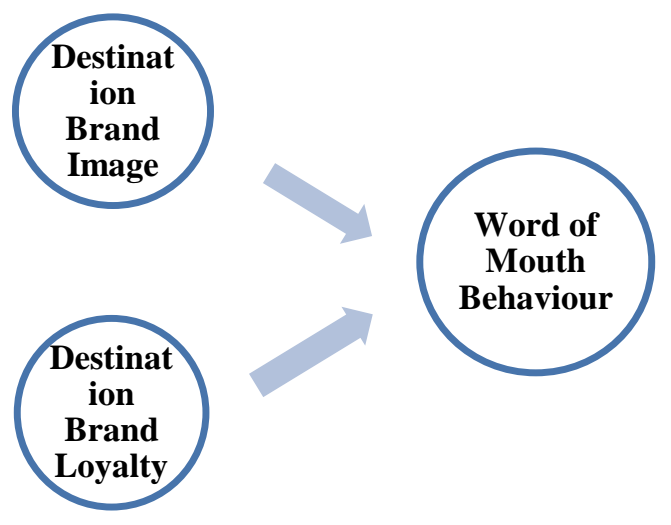

Figure 1: Research Model

Destination brand image included 4 items. Destination brand loyalty included 4 items and word-of-mouth behaviour comprimised 3 items. There were 11 items in total.

$\mathrm{H}_{1}$ The destination brand image and destination brand loyalty are positively related to word of mouth behaviour.

\section{Analysis}

The Multiple Regression Analysis was performed in order to examine the relationship between destination brand image, destination brand loyalty and WOM behaviour.

Main assumptions of Multiple Regression Analysis as error term normality, autocorrelation and multicollinearity was checked before the analysis. Error-term normality was checked by Kolmogorov-Smirnov. Error-term distributed normally (sig.=0,259)

Autocorrelation was checked by Durbin-Watson test. Durbin-Watson (D-W)=1,979. Since it is close to 2 , it can be considered that there is no autocorrelation in model. Multicollinearity was checked by VIF. Since the VIF values are less than 5 , it can be considered that there is no multicollinearity between the independent variables.

The Multiple Regression Analysis results are below:

\begin{tabular}{|c|c|c|c|c|c|c|c|c|c|c|}
\hline \multirow[b]{2}{*}{ Model } & \multirow[b]{2}{*}{$\mathrm{F}$} & \multirow[b]{2}{*}{\begin{tabular}{|l}
$\mathrm{R}$ \\
Square
\end{tabular}} & \multirow[b]{2}{*}{$\begin{array}{l}\text { Adjusted R } \\
\text { Square }\end{array}$} & \multirow[b]{2}{*}{$\begin{array}{l}\text { Std. Error of the } \\
\text { Estimate }\end{array}$} & \multicolumn{5}{|c|}{ Change Statistics } & \multirow[b]{2}{*}{$\begin{array}{l}\text { Durbin- } \\
\text { Watson }\end{array}$} \\
\hline & & & & & $\begin{array}{l}\text { R Square } \\
\text { Change }\end{array}$ & $\begin{array}{l}\mathrm{F} \\
\text { Change }\end{array}$ & df1 & df2 & $\begin{array}{l}\text { Sig. F } \\
\text { Change }\end{array}$ & \\
\hline 1 &, $697^{\mathrm{a}}$ &, 486 &, 481 & 1,83364 &, 486 & 93,052 & 2 & 197 &, 000 & 1,979 \\
\hline
\end{tabular}

a. Predictors: (Constant), destination brand loyalty, destination brand image

b. Dependent Variable: wom behaviour

\section{Table 1: Model Summary ${ }^{b}$}

The $\mathrm{R}^{2}$ is 0,486 , which means WOM can be explained by $\% 48,6$ with destination brand image and destination brand loyalty.

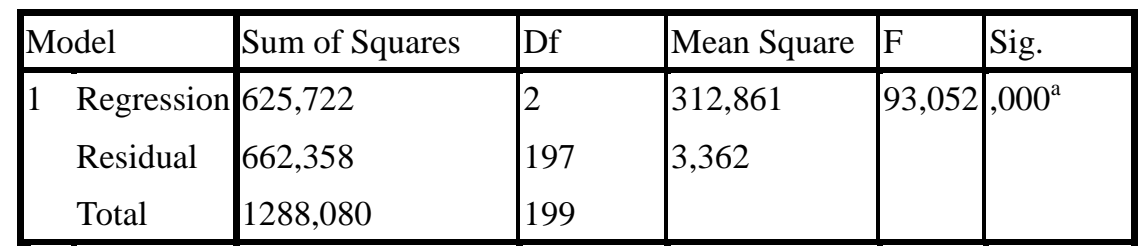

a. Predictors: (Constant), destination brand loyalty, destination brand image

b. Dependent Variable: wom behaviour

Table 2: ANOVA ${ }^{b}$

As can be seen in the above table, Sig. value is 0,00 which shows the model is generally significant. 


\begin{tabular}{|c|c|c|c|c|c|c|c|c|c|c|c|c|}
\hline \multirow[b]{2}{*}{ Model } & \multicolumn{2}{|c|}{$\begin{array}{l}\text { Unstandardized } \\
\text { Coefficients }\end{array}$} & \multirow{2}{*}{$\begin{array}{l}\text { Standardized } \\
\text { Coefficients }\end{array}$} & \multirow[b]{2}{*}{$t_{t}$} & \multirow[b]{2}{*}{ Sig. } & \multicolumn{2}{|c|}{$\begin{array}{l}95,0 \% \\
\text { Confidence } \\
\text { Interval for B }\end{array}$} & \multicolumn{3}{|c|}{ Correlations } & \multicolumn{2}{|c|}{$\begin{array}{l}\text { Collinearity } \\
\text { Statistics }\end{array}$} \\
\hline & B & Std. Error & & & & $\begin{array}{l}\text { Lower } \\
\text { Bound }\end{array}$ & $\begin{array}{l}\text { Upper } \\
\text { Bound }\end{array}$ & $\begin{array}{l}\text { Zero- } \\
\text { order }\end{array}$ & Partial & Part & Tolerance & VIF \\
\hline 1 (Constant) & 3,706 &, 640 & & 5,793 &, 000 & 2,444 & 4,968 & & & & & \\
\hline $\begin{array}{l}\text { destination } \\
\text { brand image }\end{array}$ &, 185 &, 051 &, 246 & 3,592 &, 000 &, 083 &, 286 &, 584 &, 248 &, 184 &, 558 & 1,791 \\
\hline $\begin{array}{l}\text { destination } \\
\text { brand } \\
\text { loyalty }\end{array}$ &, 369 &, 050 &, 509 & 7,447 &, 000 &, 272 &, 467 &, 672 &, 469 &, 380 &, 558 & 1,791 \\
\hline
\end{tabular}

a. Dependent Variable: WOM Behaviour

Table 3: Coefficients ${ }^{a}$

The Multiple Regression Equation is below:

Word of Mouth Behaviour $($ WOM $)=3,706+0,185$ Destination Brand Image + 0,369 Destination Brand Loyalty.

This equation shows that 1 unit increase in image will effect 0,185 unit increase in wom; 1 unit increase in loyalty will effect 0,369 unit increase in wom. Also, significancy of coefficients was examined by t-test. As a result of t- test, sig.values are equivalent to zero. Therefore, coefficients are significant.

\section{Conclusion}

The findings of this study indicate that destination brand image and destination brand loyalty have a positive impact on destination word of mouth behaviour. Therefore, this study has a practical implications for destination and tourism marketers. These managers should try to increase destination brand image and destination brand loyalty to increase word of mouth behaviour.

Although this study makes contributions to the understanding of the relationship between destination brand image, destination brand personality, and word of mouth marketing, it entails several limitations. This presentation is actually a part of a broder research which is in progress. The data is cross sectional in nature. Sample is limited to tourists visited Istanbul, this research will continue using different destinations in Turkey.

\section{References}

- Boo, S. et. al., 2009. "A Model of Customer-Based Brand Equity and its Application to Multiple Destinations”, Journal of Tourism Management, 32(2), 219-231.

- $\quad$ Bruyn, A. and Lilien, G. L., 2008. "A Multi-stage Model of Word-of-mouth Influence Through Viral Marketing”, International Journal of Research in Marketing, 25(3), 151-163.

- $\quad$ East, R. et. al., 2008. "Measuring the Impact of Positive and Negative Word of Mouth on Brand Purchase Probability”, Internetional Journal of Research in Marketing, 25(3), 215-224.

- $\quad$ East, R. et. al., 2007. "The Relative Incidence of Positive and Negative Word-of-mouth: A Multi-category Study", International Journal of Research in Marketing, 24(2), 175-184.

- Jalilvand, M. R. et. al., 2012. "Examining the Structural Relationship of Electronic Wor of Mouth, Destination Image, Tourist Attitude to Toward Destination and Travel Intention: An Integrated Approach", Journal of Destination Marketing \& Management, 1(1), 134-143.

- $\quad$ Kim, D., Magnini, V. P. and Signal, M., 2011. "The Effects of Customers' Perceptions of Brand Personality in Casual Theme Restaurants", International Journal of Hospitality Management, 30: 448-458.

- $\quad$ Lee, R. and Lockshin, L., 2011. "Halo Effects of Tourists' Destination Image on Domestic Product Perceptions", Australasian Marketing Journal, 19(1), 7-13.

- $\quad$ Lee, T. H. and Shen, Y. L., 2013. "The Influence of Leisure Involvement and Place Attachment on Destination Loyalty: Evidence From Recreationists Walking Their Dogs Urban Parks”, Journal of Environmental Psychology, 33, 76-85.

- $\quad$ Liu, C. et. al., 2012. "Relationship Between Self-congruity and Destination Loyalty: Differences Between First-time and Repeat Visitors", Journal of Destination Marketing \& Management, 1(1), 118-123.

- Pike, S. and Bianchi, C., 2011. "Modeling Destination Brand Equity in an Emerging Long Haul Market", Travel \& Tourism Research Association Europan Chapter Conference: 58037. 
- $\quad$ Stepchenkova, S. and Morrison A. M., 2008. "Russia's Destination Image Among American Pleasure Travelers: Revisiting Echtner and Ritchie”, Journal of Tourism Mangement, 29(3), 548-560.

- Sun, X. Et. al., 2013. “Developing Destination Loyalty: The Case of Hainan Island”, Annals of Tourism Research, Available Online.

- Veasna, S. et. al., 2013. "The Impact of Destination Source Credibility on Destination Satisfaction: The Mediating Effects of Destination Attachment and Destination Image", Journal of Tourism Management, 36, 511-526.

- Yoon, Y. and Uysal, M., 2005. “An Examination of the Effects of Motivation and Satisfaction on Destination Loyalty: A Structural Model”, Journal of Tourism Management, 26(1), 45-56. 